\title{
The Design of E-Commerce System in the Shrimp Paste Industry using the Method of Structured Analysis and Design Technique (SADT) to Increase Marketing
}

\author{
Yanuar Nurdiansyah ${ }^{1, *}$, Feri Wijayanto ${ }^{2}$, and Firdaus ${ }^{3}$ \\ ${ }^{1}$ Sistem Informasi, Program Studi Sistem Informasi, Universitas Jember (UNEJ), Jl. Kalimantan 37, \\ Jember 68121, Indonesia \\ ${ }^{2}$ Institute for Computing and Information Science, Radbound University Comenisulaan 4, 6525 HP \\ Nijmegen The Netherlands \\ ${ }^{3}$ Advances Informatics School, Universiti Teknologi Malaysia, Level 5, Menara Razak, Jl. Sultan \\ Yahya Petra, 54100 Kuala Lumpur Malaysia
}

\begin{abstract}
The E-Commerce system in the shrimp paste industry is designed to increase the marketing and branding of Payangan shrimp paste. The shrimp paste produced by KUB (Kelompok Usaha Bersama-Business Group) and Poklahsar (Kelompok Pengolah Pemasaran-Marketing Processing Group) consisting of a number of joint household industries is yet to meet the sales number set. Shrimp paste has several variants, such as the processed one, the raw one and one in the form of powder which constitute the result of the development of maritime research group of Universitas Jember. The target market of the product is both national and international, especially for the powder shrimp paste which is the recent innovation of the maritime research group. It is considered to be a possibility to increase the sales figures and to decrease the marketing costs by optimizing the use of the internet. In order to do so, a system should be design using Structured Analysis and Design Technique (SADT) to build an e-commerce application. It is expected that the E-Commerce application can increase the sales of the shrimp paste and reach a wider number of consumers.
\end{abstract}

Key words: E-commerce, integration definition language 0 (IDEF-0), Payangan Shrimp Paste, structured analysis and design technique (SADT),

\section{Introduction}

Coastal area is an area which serves a number of functions (multiple use zones). Payangan, located in Sumberrejo Village, Sub-district of Ambulu, is one of the coastal areas in the District of Jember - Indonesia which constitutes the second largest area for seafood processing business in Jember. The local people are mostly fishermen and seafood processors. The business of seafood processing is mostly household of which mostly produce: black shrimp paste, shrimp paste, smoked fish, and salted fish [1].

*Corresponding author: yanuar_pssi@unej.ac.id 
The products of household industry in Payangan, Watu Ulo Village, Sumberejo Village, Sub-district of Ambulu, District of Jember, East Java, have not been professionally maintained in order to produce quality and hygienic products. As a matter of fact, a lot of people have become familiar to the taste of the shrimp paste [2, 3]. It means that the marketing opportunity for the shrimp paste remains open. At present, Payangan Shrimp Paste Industry has not managed to meet the sales figures as set. The targeted market of Payangan Shrimp Paste Industry is the internet. With the development of online marketing system, a wider number of consumers can eventually be familiar with the product. By selling the product through the internet, it allows the increase of sales figures and the decrease of marketing costs. To achieve the goal, it is required a marketing system using Structured Analysis and Design Technique (SADT) to build an online-based E-Commerce application. The cost of E-Commerce business is affordable it means that by building a business on the internet, the company will get feedback from the customers.

\section{Research method}

This research used the designing SADT method and system development method [4]. To do that method, the software of life cycle development was used by adopting the iterative waterfall model.

\subsection{Structured analysis and design technique (SADT)}

Structured Analysis and Design Technique (SADT) was further supported and developed by Softech Corporation since 1974. SADT views a system as an object (objects, documents, data) and event (activities performed by people, machines or software). Moreover, SADT also uses two types of diagrams: activity diagrams or actigrams (also used in processoriented approach) and data diagrams or datagrams (also used in data/object-oriented approach).

SADT simply uses two diagrams in both process- and object-oriented approaches; that are actigram and datagrams. Compared to the other two approaches, SADT is commonly used due to the presence of a separate control activity or control II-21 activity and the fact that it is able to confirm actigrams with datagrams that the database structure is more valid. Process actigram can be seen in Figure 1.

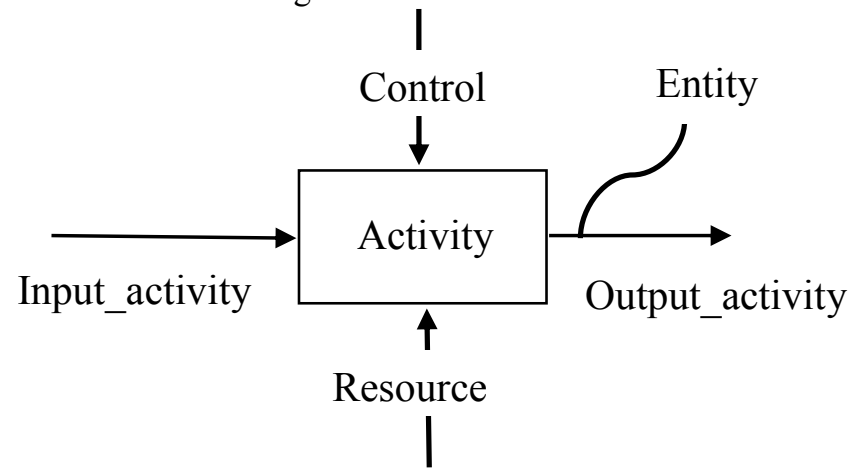

Fig. 1. Actigrams.

In Actigrams (activity diagram in SADT), there are two symbols: box indicates the activities and arrow indicates the data used by the activity (input data), data generated by the activity (output data), control data (constraints), support mechanisms shows the department or individual which is in charge of the activity. 


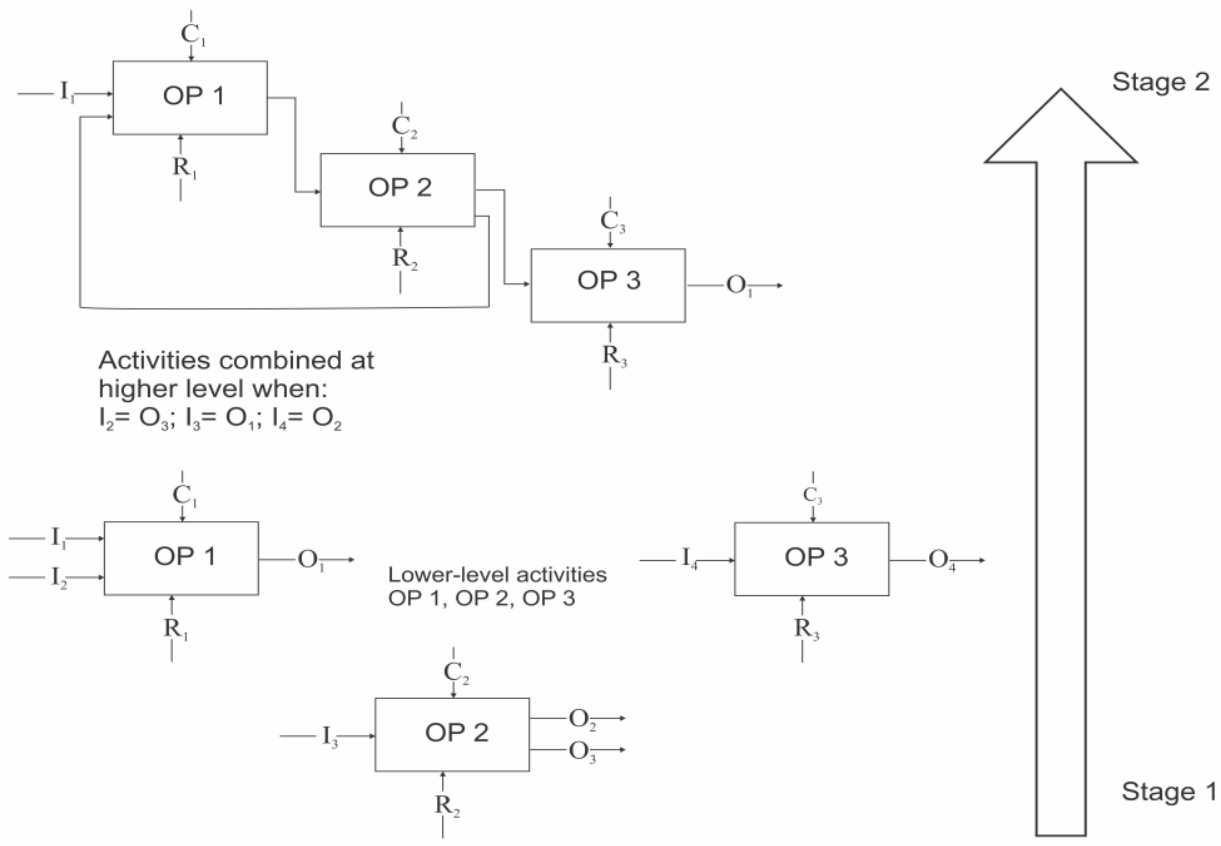

Fig. 2. Datagrams.

In Datagrams (data diagram in SADT), there are two symbols: box indicates the data and arrow indicates the activity. Control Activity limits the data generating activity and the activity that uses II-22 data. The storage mechanism is the outer storage file used to obtain the data. Such control activity limits the data-generating activity and data-oriented activity as well as corrects the existing structured data used in the process involved (processoriented activity). Thus, the generated database is in accordance with the system. Datagram can be seen in Figure 2.

SADT has the following advantages:

i). Easy to learn;

ii). A suitable communication means between system analysis and system users in the process of system development;

iii). Providing system design documentation; and

iv). Producing similar solutions with precise design specifications for system designers.

However, SADT has the following disadvantages:

i). Time consuming and more personnel needed;

ii). In general, the method is suitable for analysis and design, but in terms of detailed design, the system analysis must employ another methodology;

iii). The application requires expertise and experience of the analyst.

\subsection{E-Commerce}

Electronic Commerce or generally known as E-Commerce is a new concept or process of buying and selling goods or services on the internet [5]. The implementation of Electronic Commerce began in the early 1970s with the innovation of electronic transfers (EFT) [6]. At that time, the application was limited to large companies, financial institutions, and few small companies. Electronic Data Interchange (EDI) was established 
which evolves from financial transaction to other transaction and enlarges the number of the participating companies, at the same time [7]. Therefore, the term E-Commerce is a narrow term for few people. Many prefer to use the term e-business, which refers to the broad definition of E-Commerce, which means that it does not merely revolves around selling and buying, but also serving customers and collaborating with business partners, as well as electronic transaction within an organization.

In the history, only few numbers of innovations were noted to gain many potential advantages as E-Commerce. The global technology nature, low cost, the chance of reaching to millions of people, the interactive nature, and the rapid development have gained many benefits for organizations, individuals and communities.

\section{Discussion}

\subsection{System design}

This stage of study provides a general overview about the identification regarding the needs of the data information. It is used to design the outline of the system. The model was formulated as a function which describes the relationship among the objects in the process of the e-commerce system [8]. The system was designed and developed using websitebased PHP programming language of which users consist of two entities: the seller/admin and the customer/user. In the application, the login form is available for two user accesses in which the application can run in different PC, be it computer, laptop, or mobile. The processes for each user are:

i). Seller/admin: to facilitate the data entry regarding the shrimp paste which is available to purchase; to display the report data to be printed.

ii). Customer/user: to facilitate the data entry regarding the shrimp paste purchased using a digital cart which accommodates a number of items ordered along with the shipping cost.

\subsection{Data diagram}

In SADT, the data diagram also uses box and arrow symbols. The box symbol indicates the data and the arrow symbol indicates the activity associated with the data. Datagram of Shrimp Paste E-Commerce can be seen on Figure 3. 


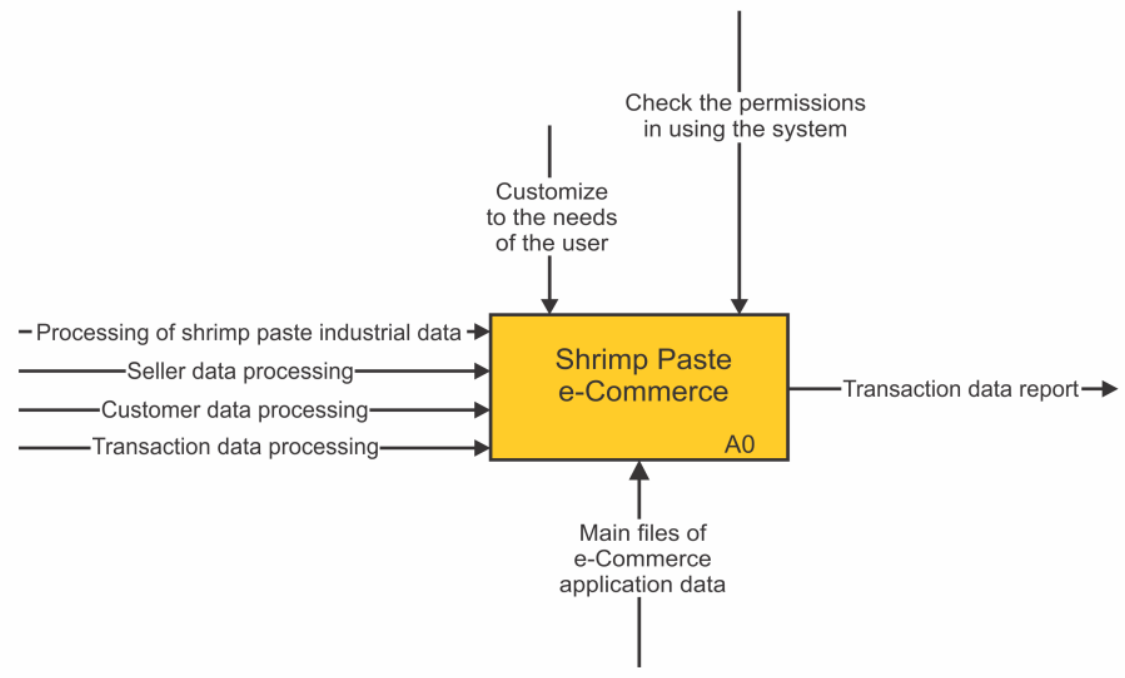

Fig. 3. Datagram of shrimp paste E-Commerce

In the Payangan Shrimp Paste E-commerce datagram, there are a number of data processing inputs performed by the system, including the data processing of shrimp paste by the industry, the seller data, the customer data and the transaction which is controlled by the system access based on the needs of the user $[9,10]$. The output is in the form of transaction data which constitutes the report of the transaction data. All input and output data are stored in the database of the E-Commerce application. Actigram SADT of shrimp paste data management can be seen on Figure 4 and Actigram SADT of transaction data can be seen on Figure 5.

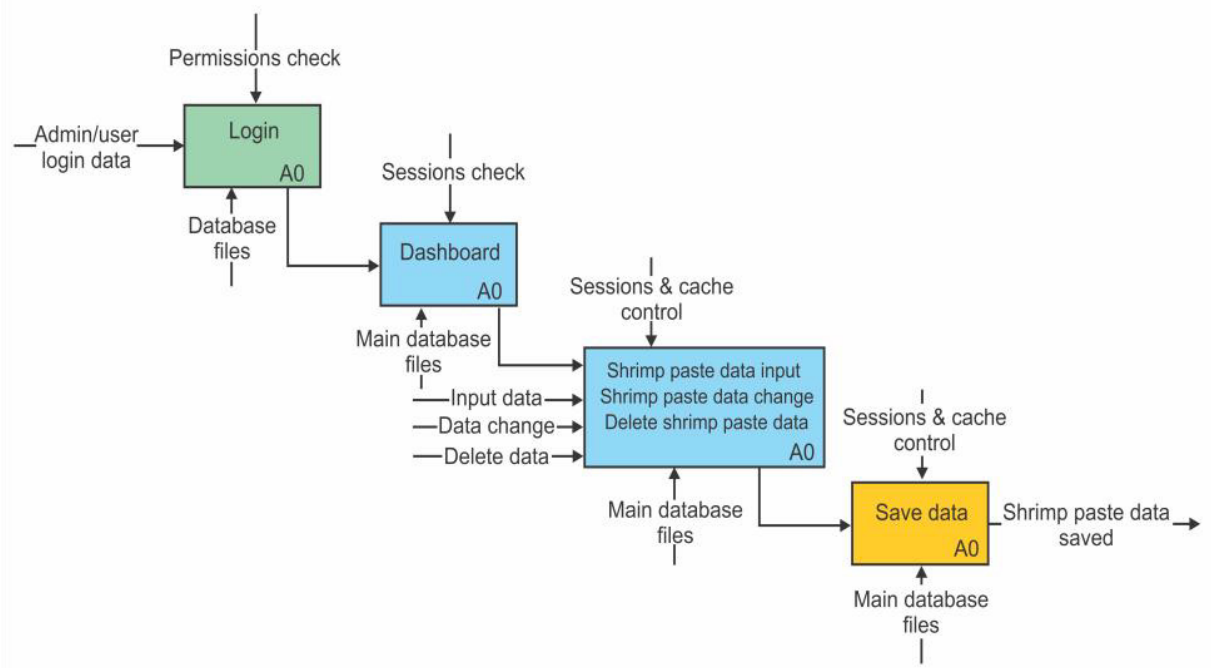

Fig. 4. Actigram SADT of shrimp paste data management. 


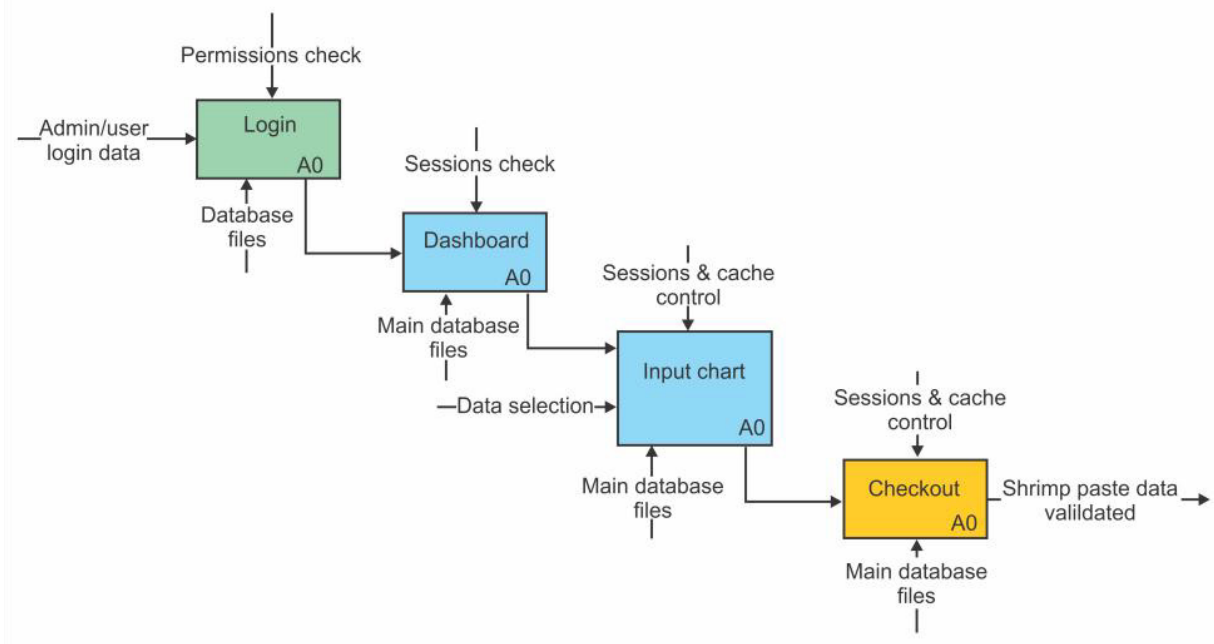

Fig. 5. Actigram SADT of transaction data.

Furthermore, the E-Commerce datagram is divided using the integration definition language 0 (IDEF-0) technique to generate the actigram from each business process performed within $[11,12]$. There are two main business activities in the E-Commerce system of Payangan Shrimp Paste: the shrimp paste data management and the transaction data management.

The process of shrimp paste data management, which is conducted completely by the seller of the shrimp paste products, includes the management of the shrimp paste along with the price. Meanwhile, the transaction data management includes the role of the customer (user) and the seller (admin) in which the customer orders the shrimp paste product by selecting the item, then proceed to the checkout to see the cost to pay including the shipping cost; afterwards, order verification is conducted by the seller and the shrimp paste is ready for delivery to the customer.

\section{Conclusion}

A number of conclusions are drawn from the design and the implementation of the Payangan shrimp paste E-commerce.

i. Payangan shrimp paste E-Commerce which was developed can help increase the sales performance by providing digital information which is accessible for everyone.

ii. Structured Analysis and Design Technique (SADT) model using Integration Definition Language 0 (IDEF0) approach, a language of definition and graphic model (syntax and semantics) which describes a comprehensive methodology to develop the model, is applicable to this application because it structurally models the whole business processes from the lowest to the highest level.

\section{References}

1 B. Sobhi, M.N. Adzahan, M.S.A. Karim, R. Karim. Journal of Food, Agriculture and Environment 8,1:38-40 (2010). 
https://www.researchgate.net/publication/292566565_Physicochemical_and_senso ry properties of a traditional_chilli_shrimp_paste

2 J. Pongsetkul, S. Benjakul, P. Sumpavapol, O. Kazufumi, N. Faithong. International Aquatic Research, 6,3:155-166 (2014). https://link.springer.com/article/10.1007\%2Fs40071-014-0076-4

3 J. Pongsetkul, S. Benjakul, P. Sumpavapol, K. Osako., N. Faithong. Journal of Food Processing and Preservation, 40,4:636-646 (2015a).

https://onlinelibrary.wiley.com/doi/abs/10.1111/jfpp.12643

4 M.E. Dickover, C.L. Mcgowan, D.T. Ross. Software design using: SADT. ACM '77 Proceedings of the 1977 annual conference. 16-19 October 1977. (Seattle, Washington, 1977). ACM, pp. 125-133 (1977). https://dl.acm.org/citation.cfm?id=810192

5 Y.A. Nanehkaran. International Journal Of Scientific \& Technology Research, 2,4:190-193 (2013). http://www.ijstr.org/final-print/apr2013/An-Introduction-ToElectronic-Commerce.pdf

6 M. Niranjanamurthy, D. Chahar. International Journal of Advanced Research in Computer and Communication Engineering, 2,7:1-12 (2013).

https://www.ijarcce.com/upload/2013/july/69-o-Niranjanamurthy $\% 20$ The $\% 20$ study $\% 20$ of $\% 20 \mathrm{E}-$ Commerce\%20Security\%20Issues\%20and\%20Solutions.pdf

7 D. Pandey, V. Agarwal. International Journal of Advanced Research in Computer Science and Software Engineering, 4,3:669-671 (2014).

https://www.researchgate.net/publication/291903546_Ecommerce Transactions_An_Empirical_Study

8 M.O. El-fitouri. International Journal of Engineering Research and Applications, 5,1( Part 1):102-115 (2015).

https://pdfs.semanticscholar.org/f86b/37506f7972d0c46694d5f94c035a5d2a0279. pdf

9 J. Singh. International Journal of Innovative Research in Computer and Communication Engineering, 2,2:2850-2858 (2014). http://www.ijircce.com/upload/2014/february/1 Review.pdf

10 Y.Y. Zhu. International Journal of Security and Its Applications, 7,6:259-268 (2013).

https://pdfs.semanticscholar.org/485a/96ef603d0ddaa906469fb7fd8080840eeb73.p df

11 C.-H. Kim, R.H. Weston, A. Hodgson, K.-H. Lee. Computers in Industry, 50,1:35-56 (2003). https://www.sciencedirect.com/science/article/pii/S0166361502001458

12 J.A.B. Montevechi, F. Leal, A.F. De Pinho, R.F. Da Silva Costa, M.L.M. De Oliveira, A.L.F. Da Silva. Conceptual modeling in simulation projects by mean adapted IDEF: An application in a Brazilian Tech Company. Proceedings of the 2010 Winter Simulation Conference. 5-8 December 2010 (Baltimore, Maryland, 2010). pp. 1624-1635.

https://dl.acm.org/citation.cfm?id=2433708\&dl=ACM\&coll=DL 